\title{
Aristotle on Identity and Persistence ${ }^{1}$
}

John Bowin

In antiquity, the problem of persistence through time is usually associated with certain puzzles or paradoxes, such as the Ship of Theseus ${ }^{2}$ and Epicharmus' Growing Argument, ${ }^{3}$ which call into question the assumption that an enduring entity can gain and shed properties while still remaining numerically the same. ${ }^{4}$ Although Aristotle gives ample attention in the Physics to the Zenonian paradoxes of motion, he makes no mention of puzzles that focus mainly on problems of persistence, except for one brief reference in Physics Book 4, chapter 11. The reference occurs in a discussion of time, where Aristotle tries to account for the fact that 'the now' is in a way always the same and in a way always different. The puzzle in question is alluded to when he claims at 219b18-22 that a moving thing like a stone has this same feature:

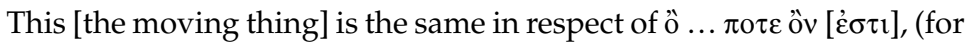
it is a point or a stone or something else of the kind); but in definition it is different, in the way in which the sophists assume that $\tau$ ò Kopírov

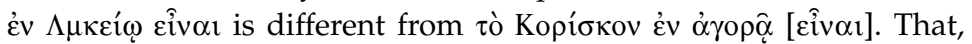
then, is different by being in different places. (Ph IV 11, 219b18-22)

1 I would like to thank R. James Hankinson, Alexander Mourelatos, Stephen White, Paul Woodruff and especially Richard Sorabji for their comments on drafts of this paper. Work on this paper was funded, in part, by a National Endowment for the Humanities Summer Stipend. Any views, findings, conclusions ro recommendations expressed in this publication do not necessarily reflect those of the National Endowment for the Humanities.

2 Plutarch Vita Thesei, 22-3

323 B 2 Diels-Kranz

4 I shall take 'identical' and 'numerically the same' to be synonymous. 


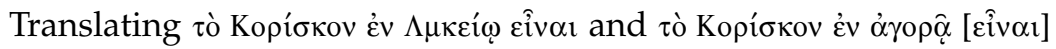
poses a problem. The most natural translation of the Greek is 'Coriscus' being in the Lyceum' and 'Coriscus' being in the market-place' respectively. But on this reading, what the sophists assume is irrelevant to the point that Aristotle is making. In the preceding two lines, Aristotle is making a point about difference and sameness in individual things or objects like stones, yet his example from the sophists is about difference and sameness in states of affairs (i.e., Coriscus' being in the Lyceum and Coriscus' being in the marketplace). One interpretative option is to assume that, in spite of what Aristotle actually says, he means to say that it is Coriscus himself, rather than a state of affairs involving Coriscus, that is different in definition. This is the interpretation of Simplicius, who claims that the sophistical puzzle alluded to is one in which 'the same' Coriscus 'becomes different from himself' by changing his place:

[The sophists] said that 'the same Coriscus is sometimes in the market-place and sometimes in the Lyceum. He who is sometimes in the market-place, sometimes in the Lyceum, becomes different from himself.' (In Phys 723 14-16)

But this is not quite satisfactory, even apart from the fact that it is not what Aristotle says. Since the 'assumption' is attributed to the sophists, one would think that it must have been the subject of a puzzle or a paradox like the Growing Argument or the Ship of Theseus. But if 'becoming different from oneself' is as Simplicius describes it, then it is hard to see what is puzzling about it, and why this phenomenon should be of any interest to a sophist. There is an air of paradox in the phrase 'becoming different from oneself', ${ }^{5}$ but to say that 'the same Coriscus is sometimes in the market-place and sometimes in the Lyceum' seems entirely straightforward.

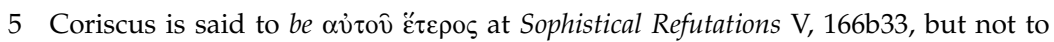

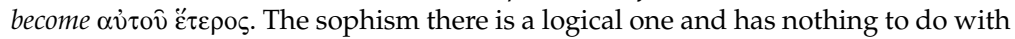
change. It trades on an equivocation between the 'is' of predication and the 'is' of identity: Coriscus is different from a man. Coriscus is a man. Therefore Coriscus is different from Coriscus. The phrase 'becoming different from oneself' also sounds suspiciously Platonic, since it turns up repeatedly in several $\dot{\alpha} \pi$ opí $\alpha$ on change in the second part of the Parmenides. (See Parm 138c1-2, 139b5-6, 139c2-3, 139e4-4, 140a8; see also, 'older/younger than oneself': 141a2-4,7, 141b1-2, 141c3-4, 141d2-3, 152d5-6, 152e2-3,9.) Simplicius may well be syncretising Aristotle with Plato here. 
It is possible, however, using a slightly less natural reading of the Greek, to take the sophists to be concerned with a genuine metaphysical puzzle that is relevant to the point Aristotle is making (that is, a puzzle that envisages differences in individual things or objects, not in

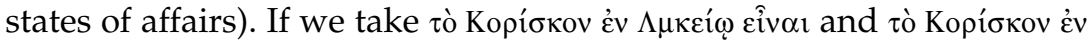

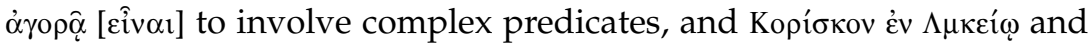

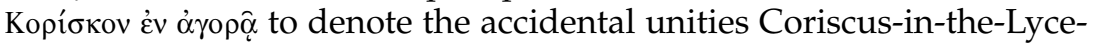
um and Coriscus-in-the-market-place, what the sophists assume is that being Coriscus-in-the-Lyceum is not the same thing as being Coriscusin-the-market-place. ${ }^{6}$ We know, from Aristotle, that the sophists envisaged accidental unities. An interest in 'cultured-Coriscus' is implicitly ascribed to the sophists in Sophistical Refutations 22, since the Sophistical Refutations is a tract on sophistical arguments. The two following attributions, however, are explicit:

The arguments of the sophists deal, we may say, above all with the accidental; e.g. the question whether "cultured" and "lettered" are different or the same, and whether "cultured-Coriscus" and "Coriscus" are the same ... (Metaph VI 2, 1026b15-18)

Generally, if it is necessary to distinguish as the sophists do, [the good man] is related to himself as Coriscus to good-Coriscus. For it is clear that some identical portion of them is good; for when they blame themselves, they kill themselves. (EE VII 6, 1240b24-27)

'Coriscus', like 'Socrates' and 'Callias', is often used by Aristotle as a stock name for an individual human being, so we cannot put too much weight on the name alone. Still, I think that it is probably more than a coincidence that on each of these two occasions where a puzzle about someone named 'Coriscus' is attributed to the sophists, the puzzle fea-

6 This is the approach taken by Sarah Broadie ('A Contemporary Look at Aristotle's Changing Now' in R. Salles, ed., Metaphysics, Soul, and Ethics in Ancient Thought (Oxford 2005), 88) who claims that 'The Greek name of each location appears in the dative inside a distinct complex monadic predicate formed with the preposition en.' The same idea is presumably behind Edward Hussey's hyphenated transla-

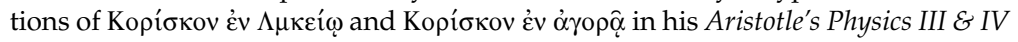
(Oxford 1983), 45. Like Hussey and Broadie, I will adopt the convention of using hyphenation to translate Greek expressions that I take to be complex predicates. 
tures accidental unities denoted by expressions like 'cultured-Coriscus', and 'good-Coriscus'.

If the sophists assume that being the accidental unity Coriscus-inthe-Lyceum is different from being the accidental unity Coriscus-inthe-market-place, and that these are different in definition, then the sophists' claim may well be that they are numerically different. ${ }^{7}$ We can easily reconstruct an argument to this effect by giving the sophists the principle that Aristotle himself enunciates at Topics VII 1, 152b25-9: if two objects are numerically the same, then they share all the same predicates. ${ }^{8}$ Since being in the Lyceum and being in the marketplace are incompatible, the sophists can infer that Coriscus does not have all the same predicates when he is in the marketplace and when he is in the Lyceum, and therefore that Coriscus, when he is in the marketplace, is numerically different from Coriscus, when he is in the Lyceum. Perhaps, then, 'Coriscus-in-the-Lyceum' and 'Coriscus-in-the-market-place', in the sophists' view, denote things that are numerically different.

Under this interpretation, the sophistical puzzle referred to at Physics IV 11, 219b18-22 posits a plurality of numerically different entities,

7 Cf. Broadie ('A Contemporary Look', 87-8) who suggests that the sophists' paradox 'presumably consisted in the claim that it is a different Coriscus in each place'.

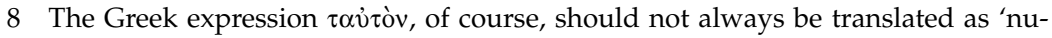
merically the same' or 'identical' or symbolized with the ' $=$ ' sign, but only when its use corresponds to what we mean by these expressions. It is my view, however, that the relation $R x y$ is what we mean by numerical sameness or identity just in case $\forall x \forall y(\mathrm{R} x y \rightarrow \forall \mathrm{F}(\mathrm{F} x \leftrightarrow \mathrm{F} y))$. Since this condition is satisfied by the use of $\tau \alpha-$ vं òv at Topics VII 1, 152b24-9, we should translate $\tau \alpha$ vं $\tau$ òv there as 'numerically the same' or 'identical' and symbolize it with the ' $=$ ' sign. Mignucci (M. Mignucci, 'Puzzles about. Identity. Aristotle and His Greek Commentators', in W. Wiesner, ed., Aristoteles: Werk und Wirkung, vol 1, 1985, 59) disagrees that Topics VII 1, $152 \mathrm{~b} 24-9$ satisfies this condition because it adds the claim that what are $\tau \alpha \hat{v} \tau \alpha$ are predicated of the same things to the claim that what are $\tau \alpha \hat{v} \tau \alpha$ have all the same predicates. Mignucci argues that since substances are, by definition, not predicated of anything ( $A n \operatorname{Pr}$ I 27, 43a25-9), what is stated cannot be a law that applies to substances, and, therefore, what are $\tau \alpha \hat{\tau} \tau \alpha$, here, cannot include substances. But as Mignucci himself admits, it is not necessary to read these two claims as constituting a single law ranging over a single domain. One could read the passage as stating two laws, one for substances and one for attributes, i.e., $\forall x \forall y(\mathrm{R} x y \rightarrow \forall \mathrm{F}(\mathrm{F} x \leftrightarrow$ $\mathrm{Fy}))$ and $\forall \mathrm{F} \forall \mathrm{G}(\mathrm{RFG} \rightarrow \forall x(\mathrm{~F} x \leftrightarrow \mathrm{G} x))$ respectively. Matthews (Gareth B. Matthews, 'Accidental Unities', in Language And Logos (Cambridge 1982), 233-4) argues that the relation at Topics VII 1, 152b24-9 is looser than identity on the assumption that the principle is tightened in Sophistical Refutations 24, 179a37-9 and Physics III 3, 202b14-6. I shall argue below that this assumption is mistaken. 
not a single Coriscus simpliciter who is 'sometimes in the market-place, sometimes in the Lyceum' as Simplicius suggests. Indeed, seeing a plurality of entities here is a more natural inference from Simplicius' diagnosis of the sophists' error than the one that Simplicius himself draws. Simplicius says that the sophists transferred the difference in account of the moving thing to the moving thing's substrate and in so doing,

... did not take notice of the way in which 'different' was taken, but rather transformed contingent into essential difference. So [Aristotle] showed that it was sophistical to think that through the before and after being different in account they were therefore different in substrate. (In Phys 723 16-20) ${ }^{9}$

But if a thing that is diverse in account is also diverse in substrate, then it seems more plausible that it is numerically diverse as well, not numerically the same yet somehow different from itself.

I propose, then, that sophist's puzzle is raising a question similar to the one just quoted from Metaphysics VI 2, viz., whether Coriscus-in-the-Lyceum is indeed numerically the same individual as Coriscus-in-the-market-place. And if the sophists are suggesting that Coriscus-in-the-Lyceum becomes Coriscus-in-the-market-place, and that these are numerically distinct individuals, then he clearly does so by being replaced by Coriscus-in-the-market-place. So just as in the Growing Argument, a change of size results in a change of identity, so in the puzzle about Coriscus-in-the-Lyceum and Coriscus-in-the-market-place, a change of place results in the emergence of a new individual. What this implies, if we generalize from the case of local motion to change as such, is that entities cannot gain and shed properties while remaining numerically the same, and since entities are always undergoing some change or other (even if it is only a relational change), the puzzle also threatens the assumption that objects persist through time. ${ }^{10}$

9 Philoponus' diagnosis of the sophists' error is the same as Simplicius', as is his claim that the crux of the puzzle involves Coriscus becoming 'different from himself'. (In Phys 728 4-8)

10 Cf. Broadie ('A Contemporary Look', 88) who suggests that the sophists' 'paradox lends itself to a variety of uses: it might be adduced to show that nothing persists through a change, or that it is unjust to arrest Coriscus in the agora for a crime "he" committed in the Lyceum, since as long as Corsicus stays away from the Lyceum the perpetrator does not exist.' 
Aristotle's response to this puzzle is evidently to claim 'This [the

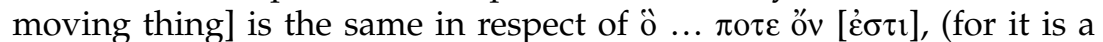
point or a stone or something else of the kind); but in definition it is different.' But what does this mean? The phrase ô $\pi$ o $\varepsilon$ ôv is notoriously difficult to interpret. It occurs nine times in the Aristotelian corpus,

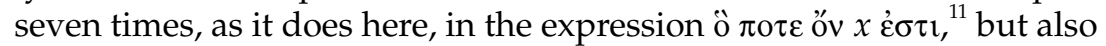

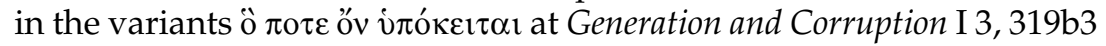

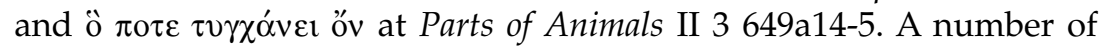

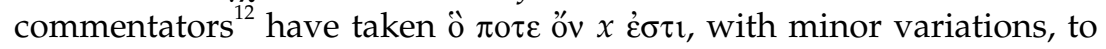
mean 'that, whatever it is, by [means of] being which, $x$ is [what it is]' where $x$ is the subject of $\dot{\varepsilon} \sigma \tau 1$, and the öv is construed as circumstantial with an explanatory force. Bostock interprets the $\pi$ o $\tau \varepsilon$ in ö $\pi$ o $\tau \varepsilon$ ö $v x \dot{\varepsilon} \sigma \tau \imath$ temporally, however, which gives us 'that, by [means of] being which at any time, $x$ is [what it is] ${ }^{13}$ Coope faults this interpretation for making 'nonsense' of Physics IV 14, 223a26-8, where the value for $x$ in ö $\pi$ o $\varepsilon$ öv $x \dot{\varepsilon} \sigma \tau \imath$ is 'time', since this would have Aristotle saying that 'time was at a time'. ${ }^{14}$ But this is only superficially nonsensical, since we commonly give the time of a time when we say 'it is now 4:00 p.m.'. for instance. 'Now' is a time, and so is '4:00 p.m.'. 'It is now 4:00 p.m.'. gives the time (viz., 4:00 p.m.) of a time (viz., now) ${ }^{15}$ We cannot, therefore, rule out a

11 The $\dot{\varepsilon} \sigma \tau \mathrm{l}$ may be either explicit or implied as it is here. At Physics IV 11, 220a6-9 the $\dot{\varepsilon} \sigma \tau \imath$ is also implied, but it is explicit at 219a20-1, 219b12-15, 219b26-8, 4.14, 223a268, and at Parts of Animals II 3, 649b24.

12 A. Torstrick, 'Ho pote on. Ein Beitrag zur Kenntnis des aristotelischen Sprachgebrauchs', Rheinisches Museum für Philologie 12 (1857) 161-73; R. Brague, Du temps chez Platon et Aristote (Paris 1982); Edward Hussey, Aristotle's Physics III \& IV; Ursula Coope, Time for Aristotle: Physics IV 10-14 (Oxford 2005).

13 Bostock comments on the occurrences of the expression at Physics IV 11, 219a20-1 and 219b26-8. (David Bostock, 'Aristotle's Account of Time', Phronesis 25 [1980], 150.).

14 Ursula Coope, Time for Aristotle, 174

15 Although Coope rejects it, many commentators have found a doctrine of a persisting 'now' in Book IV of the Physics: (W. D. Ross, Aristotelis Physica (Oxford 1956), 67-8; W. Wieland, Die aristotelische Physik (Göttingen 1970), 326; G. E. L. Owen, 'Aristotle on Time', in P. Machamer and R. Turnbull, eds., Motion and Time, Space and Matter (Columbus 1976), 15-6; David Bostock, 'Aristotle's Account of Time', 158-9, 162; Edward Hussey, Aristotle's Physics III \& IV, 152-3). Aristotle repeatedly says that the now 'follows' or is analogous to the moving thing ( $P h$ IV 11, 219b22-3, 219b31-2, 220a4-6), and these commentators take the analogy to imply the persistence of both the now and the moving thing under some description. 
temporal interpretation of $\pi \mathrm{o} \tau \varepsilon$ on this ground alone. Another problem

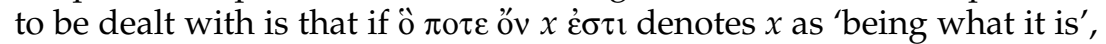
then it seems to denote $x$ under some privileged description. But what privileged description? Coope points out that it cannot be $x$ as it 'really' is because this would imply that time was really change at Physics IV 14, 223a26-8, which Aristotle refutes at Physics IV 10, 218b9 $\mathrm{ff}^{16}$

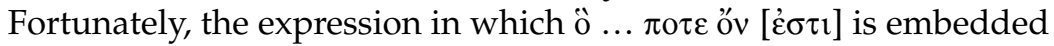
in Physics IV 11, 219b18-22, can give us some guidance. It also appears elsewhere in the Aristotelian corpus, but much more often - forty-one times, in fact, according to Bonitz - and is of the general form ' $x$ is the same in respect of $\varphi$, but it is different in respect of $\psi^{\prime 17}$ where $\varphi$ is either

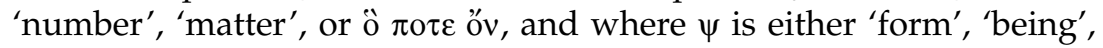
or 'definition'. It is generally agreed that the purpose of the expression is to contrast a thing's diversity in one respect with its sameness in another. But I think it has not been adequately appreciated that this sameness and diversity can be either synchronic or diachronic. That is, the contrast highlighted by this expression could be either sameness in one respect but diversity in another respect at a particular time, or sameness in one respect but diversity in another respect over time. Of the forty-one occurrences of the expression 'same in $\varphi$, different in $\psi$ ', ten are plainly concerned with diachronic diversity: At Physics IV 11, 219a20-1, what are diverse are successive phases of a change, while at 219b18-22, and 220a6-9, what are diverse are successive phases of a moving thing. At Physics IV 11, 219b10-11, 219b12-15, and 219b26-8, what are diverse are nows at various dates along a time line. At Generation and Corruption I 3, 319b3-4 \& 1.5, 320b12-14, and De caelo IV 4, 312a18-19, 312a31-3, what are diverse are the parcels of matter underlying the termini of elemental transformations (e.g., the matter of air and the matter of water involved in the elemental transformation of air into water). ${ }^{18}$ Six of these

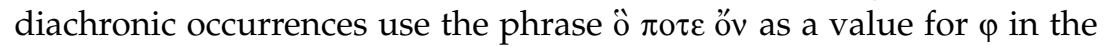

Ursula Coope, Time for Aristotle, 176.

17 I will abbreviate this as 'same in $\varphi$, different in $\psi$ ' hereafter.

18 The 31 occurrences concerned with synchronic diversity are: Top V 4, 133b34, $P h \mathrm{I}$ 2, 185b32-4, I 7, 190a15-16, 190b23-4, 190b35-191a3, III 3, 202a20, 202b8-9, 202b1112, 202b19-22, IV 6, 213a18-19, IV 13, 222a19-20, V 5, 229a18-19, VIII 8, 262a21, 262b26, 263b13-14, GC I 5, 322a25-6, DA II 12, 424a25, III 2, 425b26-7, 426a15-17, III 7, 431a13-14, 431a19-20, 431a28-9, III 9, 432a19-20, Sens 7, 449a14-16, 449a17-18, 449a19-20, Mem 1, 450b22-3, Insomn 1, 459a15-17, Metaph XII 10, 1075b4-6, EN V 1, 1130a12, VI 7, 1141b23-4. 
expression 'same in $\psi$, different in $\varphi$ ': Physics IV 11, 219a20-1, 219b12-15, 219b18-22, 219b26-8, 220a6-9, Generation and Corruption I 3, 319b3-4. ${ }^{19}$

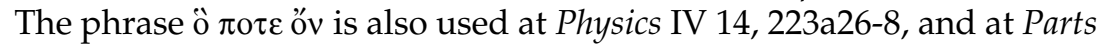
of Animals II 2, 649a14-5 and II 3, 649b24, but not as a value for $\varphi$ in this expression. In each of these three passages, however, diachronic diver-

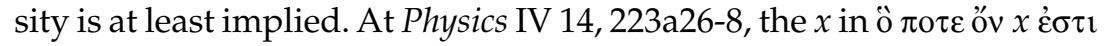
is time itself, which is diachronically diverse by definition. And the idea at Parts of Animals II 2, 649a14-5 and II 3, 649b24 seems to be that blood and bile, as successive hot and cool phases of bodily fluid, are two in being, but one in substratum, i.e., 'in respect of that, by [means of] being which at any time blood is what it is' (PA II 3, 649b23-4). So again, the diversity is diachronic.

It is more than a coincidence, I think, that each of the nine occurrences of the expression ô $\pi$ o $\varepsilon$ o oै $v$ in the Aristotelian corpus highlight diachronic diversity, ${ }^{20}$ and in the light of this, I suggest that taking the

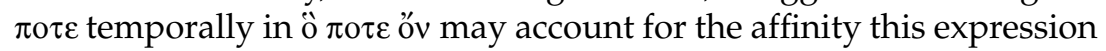
has for diachronic contexts. That is, perhaps if we take $\pi$ o $\tau \varepsilon$ temporally,

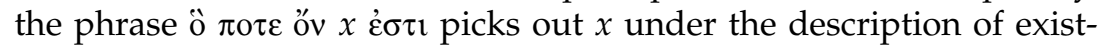
ing at various times, i.e. as persisting. And since 'being what $x$ is', for Aristotle, characteristically involves a specification of $x^{\prime}$ s function, then

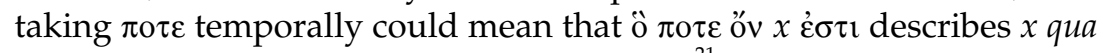
functioning as a persisting subject of change, ${ }^{21}$ as defined in Categories 5 and Posterior Analytics I $22,{ }^{22}$ i.e., as a thing which '[while] numerically one and the same, is able to receive contraries. For example, an indi-

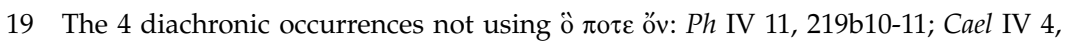
312a18-19, IV 5, 312a31-33; GC I 5, 320b12-14.

20 Six of these occurrences are as values for $\varphi$ in the expression 'same in $\varphi$, different in $\psi^{\prime}$, with five of these six clustered in Physics IV 11 and one in Generation and Corruption I 3.

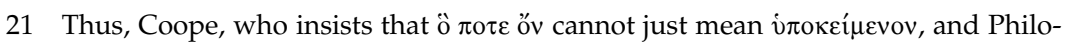
ponus and Simplicius who claim that it does, are all in a way right and all in a way wrong. Coope is right and Simplicius and Philoponus wrong, in the sense that

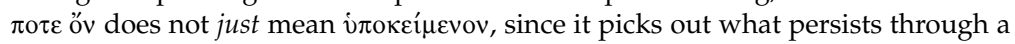
change. Simplicius and Philoponus are right and Coope is wrong, however, inso-

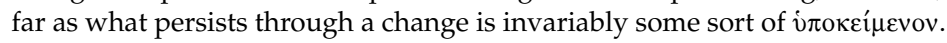

22 Posterior Analytics I $2283 a 7$ and 6-13, makes it characteristic of a substance term

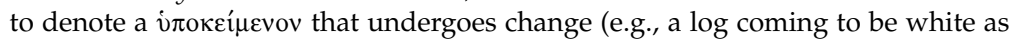
opposed to a white thing becoming a log). 
vidual man — one and the same - becomes pale at one time and dark at another, and hot and cold, and bad and good' (Cat 5, 4a17-21). ${ }^{23}$

So the whole passage is to be translated as follows:

This [the moving thing] is the same in respect of that, by [means of] being which at any time it is [what it is], (for it is a point or a stone or something else of the kind); but in definition it is different, in the way in which the sophists assume that being Coriscus-in-the-Lyceum is different from being Coriscus-in-the-market-place. That, then, is different by being in different places.

The moving thing described as that, by means of being which at any time it (i.e., the moving thing) is what it is, viz., described as a persisting subject of change, is the same over time, but the moving thing not so described - described, presumably, as just a moving thing - is different, i.e., diverse over time, 'in the way in which the sophists assume that being Coriscus-in-the-Lyceum is different from being Coriscus-inthe-market-place.' But what is the moving thing described as a moving thing, and how is it diverse in definition, as being Coriscus-in-the-Lyceum is different from being Coriscus-in-the-market-place? Moreover, how is the moving thing described as a persisting subject of change different from the moving thing described as a moving thing? As Coope points out, since the referents of ' $x$ ' and ô $\pi$ o $\varepsilon$ ö $v x$ $\dot{\sigma} \sigma \tau$ must be different things, and indeed, different sorts of things for the expression ô $\pi 0 \tau \varepsilon$

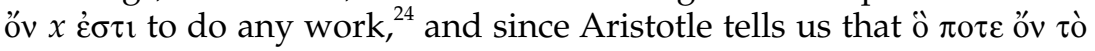

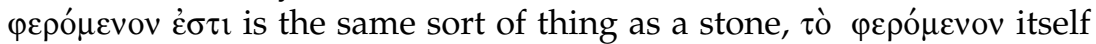
must be a different sort of thing than a stone. But if, as seems natural, we take a stone to be an example of a $\tau o ́ \delta \varepsilon \tau \imath$ and a persisting subject of change, there is at first sight a problem, since Aristotle calls $\tau$ ò $\varphi \varepsilon \rho o ́-$ $\mu \varepsilon v o v$ a $\tau o ́ \delta \varepsilon \tau l$ at Physics IV 11, 219b30. To resolve this contradiction, I

23 This is a functional specification of Coriscus described very generally as a substance. A functional specification of Coriscus described as a man would presumably include reasoning well (see EN I 7 1098a77 ff.). See David Charles, 'Simple Genesis and Prime Matter', in Aristotle: On Generation and Corruption, Book I, Sym-

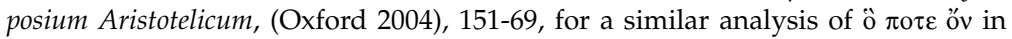
Generation and Corruption 1.3, 319b3-4. Charles takes ö $\pi$ o $\varepsilon$ öv, in this passage, to denote prime matter under the functional description of 'whatever underlies' an elemental change. 


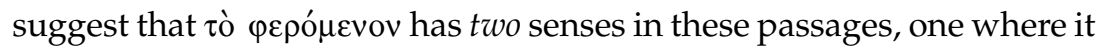
is a value for $x$ in $о 0 \pi 0 \tau \varepsilon$ ö $x \dot{\varepsilon} \sigma \tau$, and one where it is not. As a value for $x$ in ö $\pi$ o $\varepsilon$ öv $x \dot{\varepsilon} \sigma \tau \imath$, it is a $\tau o ́ \delta \varepsilon \tau \imath$ described as a moving thing. ${ }^{25}$ At Physics IV 11, 219b30 it is simply a $\tau$ ó $\delta \varepsilon \tau$. Both senses appear in the phrase 'a moving thing described as a moving thing'. The first occurrence of 'moving thing' denotes a $\tau$ ó $\delta \varepsilon \tau \imath$, and the second occurrence does not, so a moving thing described as a moving thing is a $\tau o ́ \delta \varepsilon \tau \imath$ described as a moving thing. An analogous case can be found at Physics II 1, 192b23 ff., where Aristotle, in so many words, makes the following two claims: (1) The doctor qua doctor cures patients. (2) The doctor qua man does not. Since the first occurrence of 'doctor' in the first sentence can be replaced with 'man' salva veritate while the second occurrence cannot, the word 'doctor' must be used in different senses in its first and second occurrences in this sentence.

What persisting subject of change ö $\pi$ o $\varepsilon$ öv $x \dot{\varepsilon} \sigma \tau \imath$ picks out will, of course, depend on what is substituted for $x$. In Physics IV 11, 219b18-22 and 220a6-9, $x$ is a $\tau o ́ \delta \varepsilon \tau 1$ described as a moving thing. Other values for $x$ include 'the now' at Physics IV 11, 219b12-15 and 219b26-8, 'change' at Physics IV 11, 219a20-1, 'time' at Physics IV 14, 223a26-8, and 'blood' at Parts of Animals II 3, 649b24. The last case is of special relevance, since Aristotle thinks blood is an accidental unity. I have said that Aristotle claims the sophists envisage accidental unities like cultured-Coriscus, good-Coriscus, Coriscus-in-the-Lyceum, and Coriscus-in-the-marketplace. But Aristotle also speaks of such things without dismissing them as sophistical, and this passage in Parts of Animals is a case in point, as is the mention of 'cultured-Coriscus' in Posterior Analytics I 24, and Metaphysics V 6, 'walking-Coriscus' in Physics V 4, 'cultured-Socrates' in Metaphysics V 9 and 29, 'cultured-Miccalus' in Prior Analytics I 33, and 'seated-Socrates' in Metaphysics IV 2. He even says, in the last passage, that it is the duty of a philosopher to investigate such things:

It is the function of the philosopher to be able to investigate all things. For if it is not the function of the philosopher, who is it who will in-

25 Coope and Broadie (Sarah Broadie, 'Aristotle's Now', Philosophical Quarterly 34

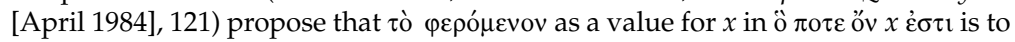
be taken as 'the thing-in-motion', i.e., 'something that is defined as being in movement'. My suggestion is only slightly different, since I take this use of $\tau$ ò $\varphi \varepsilon \rho o ́ \mu \varepsilon v o v$ to describe something that has diverse definitions. What I mean by this will be explained in the sequel. 
quire whether Socrates and seated-Socrates are the same thing ... ? (Metaph IV 2, 1004a34-b3)

The passage in Parts of Animals II 3 in which Aristotle describes blood as an accidental unity may be translated as follows:

These distinctions, then, being laid down, it is plain that blood is essentially hot in so far as that heat is connoted in its name; just as if boiling-water were denoted by a single term, boiling would be connoted in that term. But the substratum and that, by [means of] being

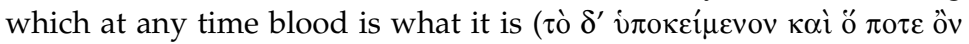
$\alpha \hat{i} \mu \alpha \dot{\varepsilon} \sigma \tau \imath v)$ is not hot. Blood then in a certain sense is essentially hot, and in another sense is not so. For heat is included in the definition of blood, just as whiteness is included in the definition of a whiteman, and so far therefore blood is essentially hot. But so far as blood becomes hot from some external influence, it is not hot essentially. (PA II 3, 649b20-7)

The claim, here, is that 'blood' refers not to a distinct type of tissue, but merely to a hot phase of bodily fluid. 'Blood' denotes an essence, but it is the essence of an accidental unity consisting of the substrate bodily fluid and the accident heat, just as 'white-man' denotes the accidental unity consisting of the substrate man and the accident whiteness. Bodily fluid is 'that, by [means of] being which at any time blood is what it is' which means that bodily fluid may get hot at one time and be called 'blood', or cold at another time and be called 'bile', but, under a certain description, it is still all the while just bodily fluid.

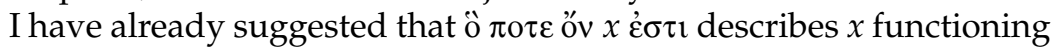
as a persisting subject of change. If the distinction between $x$ and ö $\pi \mathrm{o} \tau \varepsilon$ óv $x$ ह $\sigma \tau \imath$ is going to do any work, then $x$ must be the moving thing described as not functioning as a persisting subject of change. If, just as we can describe bodily fluid as a collection of differently defined accidental unities like blood and bile, we can describe Coriscus, when he is in motion, as a collection of differently defined accidental unities like Coriscus-in-the-Lyceum and Coriscus-in-the-market-place, then Coriscus, so described, is neither one in definition nor is he a persisting thing. Just as neither blood nor bile can become different by changing their temperatures (presumably, outside of some range), neither Coriscus-inthe-Lyceum nor Coriscus-in-the-market-place can become different by moving to different places (since they cease to satisfy their definitions as soon as they change their temperatures and places respectively). And 
just as blood cannot become bile without being replaced, Coriscus-inthe-Lyceum cannot become Coriscus-in-the-market-place without being replaced. Only bodily fluid simpliciter and Coriscus simpliciter, i.e., the persisting subject of change, can do this.

I would like to suggest, then, that in Aristotle's view, a $\tau o ́ \delta \varepsilon \tau \imath$ described as a moving thing is a $\tau o ́ \delta \varepsilon \tau \imath$ described as a collection of accidental unities, which in the case of local motion, are place-qualified entities like Coriscus-in-the-Lyceum and Coriscus-in-the-market-place. If this is the case, then it is clear that a moving thing so described cannot persist, since neither accidental unities nor any collection of them can persist through a change in their accidents. The $\tau o ́ \delta \varepsilon \tau \imath$ described as a moving thing is different in the sense of diverse in definition, insofar as it described as a collection of differently defined entities like Coriscus-in-the-Lyceum and Coriscus-in-the-market-place. So in Physics IV

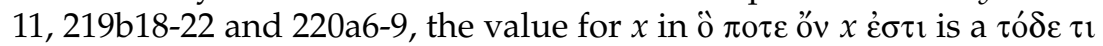
described as a moving thing, viz., a collection of accidental unities like Coriscus-in-the-Lyceum and Coriscus-in-the-market-place. ö $\pi \mathrm{o} \tau \varepsilon$ öv $x$ $\dot{\varepsilon} \sigma \tau \iota$, however, describes this collection as something functioning as a persisting subject of change, viz., as a substance (Coriscus simpliciter). This hypothesis seems to be confirmed at Physics IV 11, 220a2-4, just after the puzzle about Coriscus, where Aristotle speaks of the 'number of the moving thing'. This would make no sense unless a moving thing could be described as a plurality that could be counted.

It might seem odd to say that a $\tau$ ó $\varepsilon \varepsilon \tau$ described as a moving thing does not persist, but the rationale, I think, lies in the fact that Aristotle does not allow motion at an instant. Since this is the case, a $\tau$ ó $\delta \varepsilon \tau l$ at a single phase of a motion cannot be described as moving, since a $\tau$ ó $\delta \varepsilon \tau \imath$ described as moving is a $\tau o ́ \delta \varepsilon \tau \imath$ in multiple phases of a motion. Thus, at 219b23-5, when Aristotle says that it is by means of the moving thing that we become aware of the before and after in motion, he means that, if we regard a $\tau$ ó $\delta \varepsilon \tau \imath$ as a moving thing, we thereby become aware of that $\tau o ́ \delta \varepsilon \tau \imath$ in a plurality of its phases. ${ }^{26}$ Another apparently odd result of this interpretation is the fact that, as Broadie points out, ${ }^{27}$ a substance

26 This might seem like an 'at-at' theory of motion, but it is not, since Aristotle thinks that there is a lot more to a motion than being at different places at different times. (cf. Physics III 3). My claim is not that motion, for Aristotle, reduces to being at different places at different times, but only that it cannot be conceived of except in this way (i.e., as not occurring at any single instant).

27 Sarah Broadie, 'Aristotle's Now', 121. 
simpliciter exercises a potentiality for motion, but a substance described as moving does not. As Broadie puts it, a substance described as moving cannot be said to be 'exercising a capacity for motion as contrasted with, and rather than, rest. For it is what it is only in and through motion.'

In summary, I suggest the sophists argued that since being in the Lyceum is different from being in the marketplace, and since identical objects must have all the same attributes, Coriscus-in-the-Lyceum and Coriscus-in-the-market-place are different individuals that succeed each other in time. Aristotle counters that while Coriscus-in-theLyceum and Coriscus-in-the-market-place are different in definition, they are not different without qualification. They are also the same in respect of that, by means of being which at any time they are what they are. That is, Coriscus may be described as either a persisting substrate of change (viz., as a substance as defined in Categories 5 and Posterior Analytics I 22) or as one or more accidental unities like Coriscus-in-theLyceum and Coriscus-in-the-market-place. Described as the former, Coriscus persists, but described as the latter, he does not.

There are at least three other passages in the Aristotelian corpus where the way in which one describes an entity determines whether or not it persists: Physics I 7, 189b30-190a31, Generation and Corruption I 4 319b25-32, and Prior Analytics I 33, 47b29-37. The passage from Physics I 7 is part of a treatment of an Eleatic puzzle that seeks to prove the impossibility of change based on the fact that change under certain descriptions seems to imply generation ex nihilo. It becomes clear, however, as Aristotle solves the Eleatic problem, that change under certain descriptions also seems to threaten the persistence of objects through changes. In Aristotle's treatment, the very same change is described in the following three sentences: (i) The man becomes cultured. (ii) The uncultured (one) becomes cultured. (iii) The uncultured-man becomes the cultured-man. The key point, in regard to the issue of persistence, is that sentences (ii) and (iii) seem to involve the replacement of the thing that changes by the thing it becomes. In sentence (ii), the uncultured (one) disappears and is replaced by the cultured (one), and in sentence (iii), just as Coriscus-in-the-Lyceum is replaced by Coriscus-in-the-market-place, the uncultured-man is replaced by the cultured-man. Sentence (i), however, does not give this impression, and shows that

... there must always be an underlying something, namely that which becomes, and that this, though always one numerically, in form at least is not one. (By 'in form' I mean the same as 'in account'.) For to be 
a man is not the same as to be uncultured. One part survives, the other does not: what is not an opposite survives (for the man survives), but not-cultured or uncultured does not survive, nor does the compound of the two, namely the uncultured-man. (Phys I 7, 190a14-22) ${ }^{28}$

So just as Coriscus persists if we describe him as Coriscus simpliciter, but not if we describe him as 'Coriscus-in-the-Lyceum' or 'Coriscus-inthe-market-place', a man persists if we describe him as 'the man' but not if we describe him as 'the uncultured (one)', 'the uncultured-man', or, presumably 'the cultured-man'. The passage from Generation and Corruption I 4 makes exactly the same point in exactly the same terms ${ }^{29}$ while the passage in the Prior Analytics does the same, but substitutes 'cultured-Miccalus' for 'the cultured-man' and 'Miccalus' for 'the man', so that if we describe something as 'Miccalus', it persists, while if we describe it as 'cultured-Miccalus', it does not. ${ }^{30}$

Now by saying that a thing's persistence depends on how we describe it, Aristotle does not, of course, attribute a fabulous generative and destructive potency to our faculty of description. The point, rather, is just that a changing thing has aspects that persist and aspects that do not, and describing it under one of these aspects to the exclusion of the other can cast it as either persisting or not. The sophist gets his paradoxical conclusion that 'nothing persists' by describing the moving thing as a collection of accidental unities, which while not wrong

28 An interesting feature of this passage is that it contains a synchronic occurrence of the expression 'same in $\varphi$, different in $\psi$ ', but it makes a point about change, which is a topic that is typically associated with diachronic occurrences of the expression. And while in Physics IV 11, 219b18-22, for instance, the diversity highlighted is that of the moving thing at different phases of a motion, at Physics I 7, 190a14-22, however, the diversity that interests Aristotle is an odd sort of meta-diversity that arises from the ability to simultaneously describe something as a thing that persists or as a thing that does not, that is, as diachronically the same or as diachronically diverse. Described as 'the man', diachronic sameness is highlighted, while described as 'the uncultured-man' and 'the cultured-man', diachronic diversity is.

29 Except for the absence of 'the uncultured (one)'.

30 Note that since this point can be made, and indeed is made by Aristotle, with a definite description in one instance and with a modified proper name like 'cultured-Miccalus' in another, no special significance should be attached to the use of definite descriptions rather than proper names in Physics I 7 or GC I 4, despite Williams (C. J. F. Williams, 'Aristotle's Theory of Descriptions', Philosophical Review 94 [1985] 63-80). 
in itself, is misleading if he fails to also mention that there is another description under which it persists. We do not misdescribe a student of the fine arts merely by referring to him as 'the uncultured-man' or 'the cultured-man' nor do we misdescribe a perambulating friend by calling him 'Coriscus-in-the-Lyceum' and 'Coriscus-in-the-market-place'. Rather, we misdescribe these people if we highlight their diversity over time while slighting their sameness. The sophist's misdescription, then, is a misdescription of omission, which is what Aristotle points out when he says that the moving thing is not just diverse in definition or being, but it is also the same with respect to what persists.

\section{II}

Yet there is still a difficulty that brings to mind Aristotle's assessment of his own initial response to one of Zeno's paradoxes, viz., 'Although this solution is adequate as a reply to the questioner, ... nevertheless as an account of the fact and explanation of its true nature it is inadequate' (Ph VIII 8, 263a15-8). The difficulty I have in mind is whether the diversity in being represented by Coriscus-in-the-Lyceum and Coriscusin-the-market-place represents a diversity in beings, i.e., in entities, or just a diversity in modes of reference. There has recently been a lively debate on the question of whether, in Physics I 7, expressions like 'the man', 'the uncultured (one)', 'the uncultured-man', and 'the culturedman' denote distinct entities in Aristotle's view, or are just co-referential expressions for a single entity. ${ }^{31}$ My view is that some of these expressions are more likely to be co-referential than others. While it may be perfectly plausible to say that 'the man' and 'the uncultured (one)' corefer, it is less clear that the same can be said for 'the uncultured-man' and 'the cultured-man' since these expressions obviously conflict, as do 'Coriscus-in-the-Lyceum' and 'Coriscus-in-the-market-place'. One can, of course, point out that 'the uncultured-man' and 'the cultured-man' are meant to apply at different times, and claim, as Aristotle does, that

31 For arguments that these expressions are co-referential, see chapter 6, 155-75 of Christopher Shields, Order in Multiplicity: Homonymy in the Philosophy of Aristotle (Oxford 2003), and C. J. F. Williams, 'Aristotle's Theory of Descriptions', 63-80. For arguments that these expressions are not co-referential, see Frank A. Lewis, 'Accidental Sameness in Aristotle', Philosophical Studies 42 (1982) 1-36, and Gareth B. Matthews, 'Accidental Unities'. 


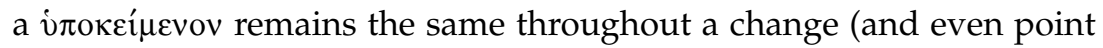
out which description of the change best reflects this assumption), but one still must reconcile the identification of the uncultured-man and the cultured-man with the principle that Aristotle himself enunciates at Topics VII 1, 152b25-9, i.e., that if two objects are the numerically the same, then they share all the same predicates. Remember that in my reconstruction of the sophists' argument at Physics IV 11, 219b18-22, it was this principle that made possible the inference that Coriscus-inthe-Lyceum and Coriscus-in-the-market-place are numerically distinct. Anyone, I think, who wants to take all of the definite descriptions at Physics I 7, 189b32-190a13 to be co-referential, as well as 'Coriscus-inthe-Lyceum' and 'Coriscus-in-the-market-place', must explain why Aristotle was not forced to draw the same conclusion.

One response might be that, in spite of the foregoing, Aristotle just means for these expressions to be co-referential, in the light of the preponderance of synchronic occurrences over diachronic occurrences of the expression 'same in $\varphi$, different in $\psi^{\prime}$, ${ }^{32}$ and the fact that in his longest digression on the expression itself in Physics Book III 3, Aristotle chooses a synchronic example (the road between Athens and Thebes that can be described as either uphill or downhill). On this view, the road between Athens and Thebes is the paradigmatic case of what is the 'same in $\varphi$, different in $\psi$ ' and all other cases are to be assimilated to it. This seems to be the assumption of Philoponus, who while commenting on Physics IV 11, 219b18-22, invokes the synchronic difference between an upward and downward staircase (an obvious adaptation of the road between Athens and Thebes) as an analogy for the diachronic difference between Coriscus-in-the-Lyceum and Coriscus-in-the-market-place (In Phys 728 8-12). But if Aristotle really thinks that terms denoting things that are the 'same in $\varphi$, different in $\psi$ ' are always coreferential, he would be guilty of a serious and fairly obvious blunder in at least three passages with diachronic occurrences of the expression 'same in $\varphi$, different in $\psi$ ' where these terms cannot possibly be co-referential. At Generation and Corruption I 3, 319b3-4 and De caelo IV 4, 312a18-19 and IV 5, 312a31-3, for instance, the matter of elemental bodies that are transforming into each other is said to be the same in subject or matter yet different in being or definition. Now obviously,

32 There are over four times as many synchronic occurrences as diachronic occurrences of this expression in the Aristotelian corpus. 
since air and water are different substances, and therefore different entities, the terms 'air' and 'water' cannot be co-referential. So nor can, presumably, 'the matter of air' and 'the matter of water', since these are parts or aspects of different entities. ${ }^{33}$ We cannot, then, invariably take the 'different' in 'same in $\varphi$, different in $\psi$ ' to be a difference in description, and cannot conclude, therefore, that 'the uncultured-man' and 'the cultured-man' are co-referential simply from the fact that they are contrasted using this particular expression. At the same time, however, we cannot infer that they are not co-referential based on an analogy from the passages just cited, since the uncultured-man and the cultured-man are accidental unities, while earth, air, fire, and water are substances, at least in the sense in which substances are defined in the Categories. On the other hand, nine of the forty one occurrences of the expression 'same in $\varphi$, different in $\psi^{\prime}$, involve sameness in number, which I think must imply co-referentiality, but these are all synchronic occurrences and, therefore, do not decide the case of the uncultured-man and the cultured-man. ${ }^{34}$

One might also think that the principle at Topics VII 1, 152b25-9 (let us follow the common practice of calling it 'the Indiscernibility of Identicals ${ }^{\prime 35}$ ) is not in play in the Physics because Aristotle has either a confused or an eccentric understanding of it. Commentators who take this view often point to the apparent restriction of this principle in Sophistical Refutations 24, 179a37-9 and in Physics III 3, 202b14-16 with the condition that only things that are the same in being have all the same attributes. It is usually claimed that in these passages, Aristotle is modifying the antecedent in the Indiscernibility of Identicals (i.e., the ' $x=y^{\prime}$ in ' $\left.\forall x \forall y(x=y \rightarrow \forall \mathrm{F}(\mathrm{F} x \leftrightarrow \mathrm{F} y))^{\prime}\right)$ so that it is satisfied by a more limited

33 Nonetheless, when commenting on GC I 3, 319b3-4, Williams invokes the road between Athens and Thebes to explain the meaning of the expression 'same in $\varphi$, different in $\psi^{\prime}$, and then assimilates this example to Frege's morning star and evening star (C. J. F. Williams, Aristotle's De Generatione et Corruptione [Oxford 1982], 96-7; cf. C. J. F. Williams, 'Aristotle's Theory of Descriptions', 75, where a Russellian analysis is substituted for a Fregean one). In her comments on the same passage, Gill is more careful (Mary Louise Gill, Aristotle on Substance: the Paradox of Unity [Princeton 1989], 250-2). She notes that the expression is not to be interpreted uniformly and suggests an interpretation in which the matters of the elements are not the same thing differently described.

34 Ph I 7, 190a15-16, 190b23-4, 190b35-191a3, Ph VIII 8, 262a21, 262b26, 263b13-14, Sens 7, 449a14-16, 17-18, 19-20

35 See note 8 above. 
domain of objects (e.g., where $\mathrm{R}_{1} x y$ means $x$ and $y$ are indistinguishable and one in substance or being, $\forall x \forall y\left(\left(x=y \& \mathrm{R}_{1} x y\right) \rightarrow \forall \mathrm{F}(\mathrm{F} x \leftrightarrow \mathrm{F} y)\right)^{6}$. In other words, it is claimed that he is modifying the sufficient condition for indiscernibility. The texts, however, plainly show him stating a necessary condition for indiscernibility instead. In Sophistical Refutations 24, he says, 'only to things that are indistinguishable and one in substance does it seem that all the same attributes belong.' In Physics III 3, 202b1416 , he says, 'it is not things which are in any way the same that have all their attributes the same, but only those to be which is the same.' If only things that have the same being or definition are indiscernible, then all things that do not have the same being or definition are discernible, and therefore all things that are indiscernible are the same in being or definition, that is, $\forall x \forall y\left(\forall \mathrm{F}(\mathrm{Fx} \leftrightarrow \mathrm{Fy}) \rightarrow \mathrm{R}_{1} x y\right)^{3}$. What Aristotle is doing in Sophistical Refutations 24 and in Physics III 3, 202b14-16 is not restricting his principle of 'identity', but, rather, delimiting or putting a necessary condition on the extension of items that are indiscernible and therefore, only indirectly and by syllogism, on the extension of items that are identical. In summary, Topics VII 1, 152b27-9 says that only indiscernibles are identical (i.e., $\forall x \forall y(x=y \rightarrow \forall \mathrm{F}(\mathrm{F} x \leftrightarrow \mathrm{F} y)))$. Sophistical Refutations 24 and Physics III 3 say that only things that have the same being or definition are indiscernible (i.e., $\forall x \forall y\left(\forall \mathrm{F}(\mathrm{Fx} \leftrightarrow \mathrm{Fy}) \rightarrow \mathrm{R}_{1} x y\right)$ ). From this we can infer, by hypothetical syllogism, that only things that have the same being or definition are identical (i.e., $\forall x \forall y(x=y \rightarrow$ $\left.\mathrm{R}_{1} x y\right)$ ). We cannot, therefore, excuse Aristotle from drawing the conclusion that Coriscus-in-the-Lyceum and Coriscus-in-the-market-place are numerically distinct because he had a weak grasp of the Indiscernibility of Identicals.

36 See, for instance White (Nicholas P. White, 'Aristotle on Sameness and Oneness', Philosophical Review 80 [April 1971], 179) and Whiting (Jennifer E. Whiting, 'Locomotive Soul: The Parts of Soul in Aristotle's Scientific Works'. Oxford Studies in Ancient Philosophy 22 [2002], 155 ff.) Matthews, ('Accidental Unities', 233-4) argues that the relation at Topics VII 1, 152b25-9 (let us call it $\mathrm{R}_{2} x y$ instead of $x=y$ ) is looser than identity, and that the conjunction of $\mathrm{R}_{1} x y$ and $\mathrm{R}_{2} x y$ in the antecedent of $\forall x \forall y\left(\left(\mathrm{R}_{1} x y \& \mathrm{R}_{2} x y\right) \rightarrow \forall \mathrm{F}(\mathrm{F} x \leftrightarrow \mathrm{F} y)\right)$ together constitute identity.

37 In general, only $F$ are $G$ is true if and only if All non-F are non-G is true, and this is true if and only if All G are F is true. 
Richard Sorabji has recently drawn attention to the relevance of Generation and Corruption I 5 to the issue of persistence over time..$^{38}$ Generation and Corruption I 5, 322a33 claims that it is the form of an organism that persists through biological growth. Sorabji points out that a form, as it is envisaged here, is quite unlike the form that is identified with the soul in de Anima II 1. In de Anima II 1, the soul as the form of the body is defined as 'the first actuality of a natural body which has life potentially' (412a27-8). A first actuality is a state ( $\left.{ }^{\prime} \xi \xi \varsigma\right)$ or disposition for certain characteristic animate activities. But in Generation and Corruption I 5, a form is a shape ( $\sigma \chi \hat{\eta} \mu \alpha, 321 \mathrm{~b} 27-8)$, and it is a shape that is said to persist as a biological organism grows larger, just as the shape of a tube ( $\alpha \dot{\lambda} \lambda$ ós) persists when the tube is inflated. ${ }^{39}$ Sorabji takes it to be an individual shape that persists, but there is reason to doubt this. First, one could plausibly claim that individual shapes have sizes, in which case, a tube could only be said to have the same type of shape before and after it grows. More troubling, however, is Metaphysics V 6, 1016a32 ff., where Aristotle characterizes things that have grown and are shrinking ( $\tau$ ò

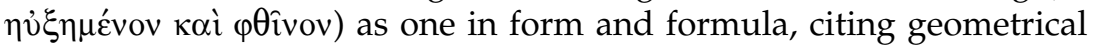
figures ( $\tau \grave{\alpha} \dot{\varepsilon} \pi i ́ \pi \varepsilon \delta \alpha)$ as examples:

Two things are called one, when the formula which states the essence of one is indivisible from another formula which shows the essence of the other (though in itself every formula is divisible). Thus even

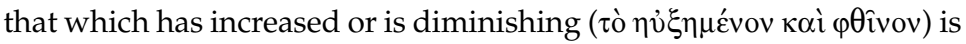
one, because its formula is one, as, in the case of planes, is the formula

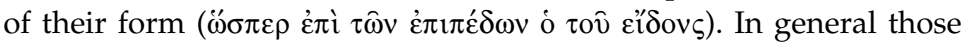
things, the thought of whose essence is indivisible and cannot separate them either in time or in place or in formula, are most of all one

38 Richard Sorabji, Self: Ancient and Modern Insights About Individuality, Life, and Death (Chicago 2006), $57 \mathrm{ff}$. See also Richard Sorabji, The Philosophy of the Commentators, 200-600 A.D., Vol. 3 (London 2004), 176.

39 C.f. Ph II 1, passim, IV 2, 209b3, VII 3, 246b15-16, Cael I 9 passim, DA I 3, 407b23-4, GA I 22, 730b14, Metaph III 4, 999b16. V 4, 1015a5, V 8, 1017b25, VII 8, 1033b6, X 1, 1052a22-3, X 4, 1055b13, X 2, 1060a23, 1060b26, XIII 2, 1077a32-3, where a thing's عî́ó $\varsigma$ is equated with its $\mu о \rho \varphi \eta$, which is, in turn, equated with a thing's $\sigma \chi \hat{\eta} \mu \alpha$ at Categories 10a11, Physics I 7, 190b15, VII 3, 245b6-7, 246a1. At Metaphysics VII 3,

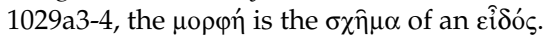


( $\mu \alpha \lambda^{\prime} \lambda \sigma \tau \alpha \ldots$ Év), and of these especially those which are substances. For in general those things that do not admit of division are one in so far as they do not admit of it, e.g. if something qua man does not admit of division, it is one man; if qua animal, it is one animal; if qua magnitude, it is one magnitude. (Metaph V 6, 1016a32-b6)

Since Aristotle is concerned with the case when 'two things are called

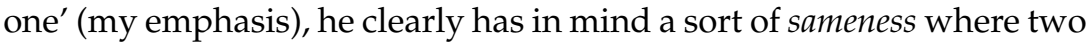
things are 'one $w i t h$ ' each other. The present participle $\varphi \theta i v$ ov suggests that this sameness is progressive or ongoing, and therefore, diachronic. So what is at issue is the diachronic sameness of a thing that is in the process of shrinking, or the unity of a larger shape prior to a change in size with a smaller shape after it. The difficulty with taking this shape to be an individual is that in the next sentence, Aristotle seems to introduce a new, stronger sense of unity (being $\mu \alpha{ }^{\prime} \lambda \tau_{1} \sigma \alpha$ Ëv) which not only requires having one form and formula, but also one time and place. ${ }^{40}$ And to make matters worse, he then goes on to distinguish being one in number from being one in form by claiming that former requires unity of matter: 'Again, some things are one in number, others in form, others in genus, others by analogy; in number those whose matter is one, in form those whose formula is one ...' (Metaph V 6, 1016b31-2). If geometrical shapes that grow and shrink had the same particular or individual form, then they would already be spatio-temporally one, and, therefore the distinction of being $\mu \alpha \dot{\alpha} \lambda ı \tau \tau \alpha$ Év would be otiose. And they would already be numerically one as well, whether or not they had the same matter, as 1016b31-2 requires. It appears, then, that the form that persists in Generation and Corruption I 5 must be a universal, not an individual. So when Aristotle says, of the growing thing, that $\tau$ ò $\delta^{\prime}$ cî̉os $\mu \varepsilon \dot{v \varepsilon 1}$ (322a33), his point must be that it retains the same type of shape over time.

If the form persists only as a universal, what, then, is the individual that persists through growth? An answer to this question is suggested by the passage in Metaphysics V 6 just quoted: 'If something qua man does not admit of division, it is one man; if qua animal, it is one animal; if qua magnitude, it is one magnitude.' Perhaps the individual that persists in Generation and Corruption I 5 is the substance or tube qua hav-

40 Kirwan also sees a distinction, here, between unity of form and formula and unity of form, formula, time, and place (Christopher Kirwan, Aristotle, Metaphysics Books $\Gamma, \Delta$, E [Oxford 1971], 138.). 
ing a certain type of shape. What we have, here, is a more informative instance of the principle that how one describes a substance determines whether or not it persists. It is more informative in the sense that what persists is not simply described as what persists (as the referent of 0

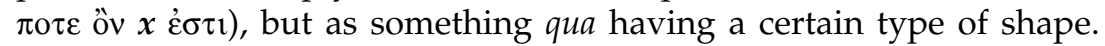
But this is not the only benefit. Describing the persisting thing as something qua having a certain type of shape can also enable Aristotle to claim that the persisting object is diachronically identical without violating the Indiscernibility of Identicals. As Jonathan Lear has pointed out, qua clauses function as 'filters' for the elimination of properties in Aristotle's discussions of geometrical objects, which instead of existing separately from physical objects, are just physical objects under certain descriptions. ${ }^{41}$ For instance, Aristotle claims that geometers study physical lines, but not qua physical, meaning that the geometer does not attend to the physical or sensible aspects of lines (Phys II 2, 194a10). To say that the organism persists qua having a certain type of shape is to treat it as a geometrical object; that is, to regard it as a thing with a certain type of shape, but not to attend to any of its other qualities. So by treating a growing organism or a tube in this way, Aristotle is able to view it in abstraction from the temporary properties (most notably but not limited to its change in size) that would make it fail the indiscernibility of identicals.

Aristotle tells us that a certain 'accuracy' and 'simplicity' is achieved by this sort of abstraction. ${ }^{42}$ For the geometer, it is useful to ignore properties that do not enter into his geometrical proofs. For someone investigating biological growth, e.g., Aristotle in Generation and Corruption I 5, it is perhaps useful to ignore those aspects of the organism not relevant to its change in magnitude, that is, everything but the properties it has when it is viewed as a three-dimensional geometrical object. In general, an Aristotelian analysis of change will involve a contrast between different levels of abstraction, where on a certain level of abstraction, an object will persist, while at a comparatively lower level, it will not. In Generation and Corruption I 5, both levels of abstraction yield geometrical objects. The more abstract object, having no particular size,

41 Jonathan Lear, 'Aristotle's Philosophy of Mathematics', Philosophical Review 91 (1982) 161-192

42 Metaph XIII 3, 1078a10-11 
will survive the change, but the less abstract ones, which have particular sizes, will not.

Generation and Corruption I 5 investigates changes in a geometrical attribute of organisms, but an analysis with a different emphasis might require one to investigate an organism under a different description. In Physics II 2 and Metaphysics XIII 3, Aristotle says that one can also view a thing qua natural, qua sensible, qua moving, qua healthy, qua female, qua male, and qua man. ${ }^{43}$ Investigating an organism qua man would presumably mean to investigate it as a substance of a particular sort, viz., having a form in the sense of a disposition for certain animate activities characteristic of the human species. One might investigate an organism qua man, for instance, if one were interested in changes in place, or alterations like becoming cultured or pale. In this case, the levels of abstraction contrasted will be, on the one hand, the organism viewed as just having its essential, species-determined properties, and, on the other hand, the unabstracted concrete organism, complete with its accidental, temporary properties. The abstract object, referred to as 'the man' or as just 'Coriscus' will persist, while unabstracted concrete organism, referred to as 'the uncultured-man' or 'Coriscus-in-the-Lyceum' will not. ${ }^{44}$

If, as I suggest, the persisting substance can be treated as an abstract object on the model of geometrical objects in Physics II 2 and Metaphysics XIII 3, then we can draw the following conclusions about the status of the persisting thing based on an analogy with geometrical objects: Aristotle claims without qualification that mathematical objects exist, ${ }^{45}$

43 Ph II 2, 194a12, Metaph XIII 3, 1077b22, 1077b28, 1078a1, 1078a6, 1078a7

44 Spellman (Lynne Spellman, 'Referential Opacity in Aristotle', History of Philosophy Quarterly 7 [1990] 17-31) also makes use of the qua locution as an abstracting device in her interpretation of accidental sames in the epistemic puzzle in Sophistical Refutations 24. The major difference between Spellman's use of this device and mine is that Spellman takes accidental expressions like 'cultured-Coriscus' to be equivalent to expressions like 'Coriscus qua the cultured (one)', and to denote abstract exemplars of kinds (e.g., of the class of cultured things). In my view, however, 'cultured-Coriscus' denotes the unabstracted Coriscus, complete with all his accidental properties like culturedness, while the name 'Coriscus' by itself denotes the abstract entity Coriscus qua man, or equivalently, Coriscus simpliciter viewed

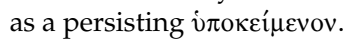


but they exist separately only in thought. ${ }^{46}$ Thus, mathematical objects are real and mind-independent. It is only their separateness that is mind-dependent. Likewise, we can say without qualification that persisting objects like a man or Coriscus or Miccalus exist, but they exist separately from the uncultured-man, Coriscus-in-the-Lyceum, or uncultured-Miccalus only in thought. Thus, substances are (of course) real and mind-independent. It is only their separateness from their ephemeral stages that is mind-dependent. But since this separateness enables the persisting object to satisfy the Indiscernibility of Identicals, and since this separateness is only in thought, it follows that the persisting object can be diachronically identical only in thought.

\section{IV}

So a certain level of abstraction is necessary for persistence in the sense that it enables Aristotle to claim that a substance persists over time without contradiction. But is there anything that is sufficient for persistence or anything that makes the persisting object diachronically identical? William Charlton has recently claimed that one will look in vain in the Aristotelian corpus for an account of what makes a substance identical over time, because for Aristotle, this is just a brute fact. ${ }^{47}$ While I am sympathetic to this claim, it is worth pointing out that Sophistical Refutations 24, 179a37-9 and Physics III 3, 202b14-16 seem to come very close to stating the Identity of Indiscernibles when they claim that only things that have the same being or definition are indiscernible (i.e., $\forall x \forall y\left(\forall \mathrm{F}(\mathrm{Fx} \leftrightarrow \mathrm{Fy}) \rightarrow \mathrm{R}_{1} x y\right)$, where $\mathrm{R}_{1} x y$ means $x$ and $y$ are indistinguishable and one in substance or being). If this is a statement of the Identity of Indiscernibles, ${ }^{48}$ then it seems, at first sight, to provide an easy answer to the question of what makes an Aristotelian substance identical over time: indiscernibility. Of course, there is still the problem that if we abstract away all but the essential properties of an entity

, $193 \mathrm{b34}$

47 W. Charlton, 'Aristotle on Identity' in Scaltsas, T., D. Charles, and M.L. Gill, eds., Unity, Identity and Explanation in Aristotle's Metaphysics (Oxford 1994), 46.

48 If this is not a statement of the Identity of Indiscernibles, then, at any rate, it is still a statement of the Indistinguishability and Oneness in Substance of Indiscernibles, which if not identity, is clearly the strongest notion of sameness that Aristotle has. 
like Coriscus, we will be hard-pressed to find anything to distinguish him from other members of the same species. This problem, I think, is intractable, which is why I am sympathetic to Charlton's view. Michael Frede has suggested that Aristotle might appeal to unique spatiotemporal histories to individuate persisting particulars that have only species attributes. ${ }^{49}$ But while this is philosophically attractive, I find no textual evidence that it is, in fact, Aristotle's doctrine. Another possibility might be to claim that abstract objects can be material and that matter individuates them, if the process of abstraction envisaged strips away properties and not matter. Thus, matter may individuate an organism qua man. In favor of this view is the fact that, as Mueller points out, Aristotle sometimes speaks of the matter of mathematical objects. ${ }^{50}$ The problem with this, however, is that it will not facilitate the re-identification of the same individual over time unless the matter remains the same over time, and we have no reason to suppose that it should.

But if diachronic identity is indeed a brute fact, and if what Aristotle has done is devise a way to make diachronic identity claims without contradiction, this is still no mean feat, since a large body of the current literature on persistence focuses on precisely this problem. Perdurantists, for instance, try to reconcile the assumption that objects persist through change with the Indiscernibility of Identicals by redefining the persisting object as a space-time worm whose stages bear the incompatible properties, rather than the worm itself. ${ }^{51}$ Aristotle, no doubt, would think that this solution requires us to abandon too many of our ordinary intuitions about what we want to call a persisting object. Modern endurantists, however, have offered an array of solutions that fare little better. One approach is to be a presentist, and claim that Coriscus' being in the market-place does not conflict with Coriscus' being in the Lyceum, because the past and future do not exist. But as David Lewis has pointed out, 'No man, unless it be at the moment of his execution, believes that he has no future; still less does anyone believe that he has

49 Michael Frede, 'Individuals in Aristotle', in Essays in Ancient Philosophy (Minneapolis 1987), $63 \mathrm{ff}$. Frede advocates individual forms, but the problem that he confronts is essentially the same, i.e., individuating something that, ex hypothesi, has only species attributes.

50 See Metaphysics XI 1, 1059b14-16, and Ian Mueller, 'Aristotle on Geometrical Objects', Archiv für Geschichte der Philosophie 52 (1970), 163.

51 David Lewis, On the Plurality of Worlds (Oxford 1986), $204 \mathrm{ff}$. 
no past. ${ }^{, 52}$ In other words, we all assume that the future and the past exist in some sense, so it will not do to just say that the past and future do not exist. ${ }^{53}$ Equally unappealing, however, are endurantists' attempts to make apparently incompatible temporary properties compatible by temporally qualifying either the properties themselves or their instantiations. ${ }^{54}$ Each of these approaches, I think, proves as costly to our intuitions about what constitutes a temporary property or how we have temporary properties as perdurantism is to our intuitions about what constitutes a persisting object. Aristotle's answer, by contrast, seems to be just a common-sense description of what we, as a matter of fact, do, when we make judgments about diachronic identity. When we see Coriscus in the Lyceum, and then later in the marketplace, we ignore or abstract away temporary properties, like being in a certain location, that he has acquired or lost in the interim. We can concede to the sophists that Coriscus-in-the-Lyceum and Coriscus-in-the-market-place are numerically distinct entities. They are fully concrete particulars, complete with their temporary properties, and are therefore non-identical. But with a little abstraction, we can also see the forest for the trees. We can see that, viewed in a certain abstract way, Coriscus-in-the-Lyceum and Coriscus-in-the-market-place are also a single entity - Coriscus

52 David Lewis, On the Plurality of Worlds (Oxford 1986), 204

53 There is also good reason to think that presentism would conflict with Aristotle's conception of time as a continuum. Miller, for instance, points out that since time is an attribute of motion, and motion does not exist at an instant, time does not exist at an instant. Therefore, if Aristotle is to say that time is real, and he does, he must commit to the reality of either the past or the future. (Fred D. Miller, 'Aristotle on the Reality of Time'. Archiv Für Geschichte Der Philosophie 56 [1974], 135.) Owen and Hussey make the slightly different point that the status of the now as a boundary of the past and future implies the reality of that which it bounds. Hussey thinks that this at least implies the reality of the past since, according to Aristotle, every moment of change is a moment of having changed. (G. E. L. Owen, 'Aristotle on Time', 20; Edward Hussey, Aristotle's Physics III \& IV , 139)

54 One might temporally qualify a property, for instance, by making it a relation to times (e.g., where the property Fxy means $x$ is in the market-place at time $y$; see Katherine Hawley, How Things Persist [Oxford 2001], 16-20.). One might qualify the having of the property by either tensing the copula (e.g., saying that Coriscus isat-time- $t$ in the Lyceum and is-at-time- $t+1$ in the marketplace; see Mark Johnston, 'Is there a Problem about Persistence?' Proceedings of the Aristotelian Society, suppl. vol. 61 [1987], 129) or using an adverbial modifier (e.g., saying that Coriscus is attime-t-ly in the Lyceum, but at-time- $t+1$-ly in the marketplace; see Sally Haslanger, 'Endurance and Temporary Intrinsics', Analysis 49 (1989) 119-125.). 
simpliciter - who persists through the local motion from the Lyceum to the marketplace. ${ }^{55}$

\author{
Department of Philosophy \\ The University of California, Santa Cruz \\ Santa Cruz, CA 95064 \\ USA \\ jbowin@ucsc.edu
}

55 As a final note, I would like to situate my interpretation within the debate about the status of accidental unities and accidental sames in Aristotle. The debate, as I see it, turns on the question of whether accidental unities and sames are numerically distinct entities, or put another way, whether or not every accidental denoting expression like 'the cultured-man' is co-referential with some non-accidental denoting expression like 'the man'. For convenience, let us call those who claim such expressions are co-referential 'deflationists', and those who claim that they are not 'non-deflationists'. See references in note 28 above. Rather than cast my lot with either the deflationists or non-deflationists, I would like to question the way in which the debate itself has been framed. The parties to the debate have typically tried to decide the ontological status of accidental unities and accidental sames as such, based on the discussions of sameness and unity in Topics I 7, and Metaphysics V 6 and 9, and then apply a general doctrine about the status of these entities to texts such as Physics I 7 and Sophistical Refutations 24. I would like to suggest that nothing requires a deflationary or a non-deflationary reading of accidental unities and sames as such. Particular accidental unities and sames may or may not be numerically distinct. Whether they should be taken as numerically distinct depends on the circumstances in which they appear and the features of the metaphysical problem that Aristotle is trying to solve. In the context of puzzles about persistence, I claim that it is philosophically and exegetically attractive to take some, but not all accidental unities and sames to be numerically distinct. For instance, Coriscus may get a suntan while walking from the Lyceum to the market-place, but it is not necessary to distinguish five entities for the account of persistence I am advocating, i.e., Coriscus simpliciter, Coriscus-in-the-Lyceum, Coriscus-in-themarket-place, pale-Coriscus and tan-Coriscus. That is, 'Coriscus-in-the-Lyceum' and 'pale-Coriscus' may indeed be coreferential, and also 'Coriscus-in-the-market-place' and 'tan-Coriscus'. But on my view, 'Coriscus-in-the-Lyceum' and 'Coriscus-in-the-market-place' may not; nor may 'Coriscus simpliciter' and 'Coriscus-in-the-Lyceum'. What matters is not so much the form of the denoting expression, but the time at which what is denoted exists and whether it is conceived of abstractly or concretely. In this example, 'Coriscus-in-the-Lyceum' and 'pale-Coriscus' co-refer to a concrete object that does not persist, while 'Coriscus simpliciter' refers to an abstract object that does persist. 